\title{
Effects of GABA on Erythropoiesis in the Hep3B Cell and Rat Exposed to Hypoxia
}

\author{
Joongsoo Yoon ${ }^{*}$ and In-Suk Sim ${ }^{\dagger ; *}$ \\ Department of Clinical Laboratory Science, Kyungdong University, Wonju 26495, Korea
}

The aim of this study was to evaluate gamma-aminobutyric acid (GABA)-induced erythropoietin (EPO) and EPOreceptor expression in human Hep3B cells and Sprague Dawley (SD) rats during hypoxia. Expression levels of EPO, EPO-R mRNA, Janus kinase-2 (JAK-2), vascular endothelial growth factor (VEGF), hypoxia inducible factor-1 (HIF-1), and HIF-2 in response to GABA treatment were evaluated in cell lines. SD rats were randomly divided into 5 groups of 8 rats each, and GABA was orally administered; the groups were the normal control (NC), hypoxia-exposed (G0), as well as the GABA $1 \mathrm{mg} / 100 \mathrm{~g}$ body weight (BW) GABA treated group (G1), $5 \mathrm{mg} / 100 \mathrm{~g}$ BW GABA treated group (G5), and $10 \mathrm{mg} / 100 \mathrm{~g} \mathrm{BW}$ GABA treated group (G10) with hypoxia. We analyzed EPO levels and red blood cell counts in rat blood and EPO gene expression in kidney tissue. EPO and VEGF mRNA levels in Hep3B cells exposed to hypoxia were significantly increased and further increased after GABA treatment. However, the expression of EPO-R and JAK-2 mRNAs were not affected by GABA, but hypoxia-induced HIF-1 and HIF-2 mRNA expression was inhibited by GABA. In the kidney tissue of rats exposed to hypoxia, the expression level of EPO mRNA was greatly increased, but levels in the GABA treatment groups significantly decreased. EPO levels in the serum showed the same significant trend, but the red blood cell counts were not significantly different. These findings demonstrate that HIF-1 and HIF-2 activation increase EPO expression in Hep3B cells exposed to hypoxia. However HIF decreased by GABA addition and VEGF increased significantly.

Key Words: GABA, Hypoxia, Hep3B cell, Erythropoiesis, Rat

\section{서 론}

인체는 산소농도 변화에 민감하게 반응하여, 이에 적응 하는 세포 및 개체의 활동은 생존에 필수적이며, 항상성 유지에도 매우 중요하다(Semenza, 2000). 특히, 고지대와 같은 저산소 상태(hypoxia)에서는 신체의 적응 반응을 자 극시키기 위해 산소운반을 증가시키며, 이에 관여하는 단 백질이 크게 발현되어 저산소 상태에 적응한다(Mazzeo, 2005). 저산소에 2 3일간 노출되면 적혈구 조혈인자(ery- thropoietin, $\mathrm{EPO})$ 의 분비가 증가되고, 3 주 이후에는 적혈 구, hemoglobin, hematocrit이 증가된다(Levine and StrayGundersen, 1992; Chapman et al., 1998). 뿐만 아니라, 호흡 증가, 혈관 확장, 혈관 신생의 증가, gluconeogenesis의 감 소, ATP 생성 반응 감소 등의 현상이 나타나며, 이 중 혈 관 신생이 가장 장기적이고 효과적인 적응 반응이다.

Gamma-aminobutyric acid (GABA)는 중추신경계에서 억 제성 신경전달 물질이며, 말초 비신경계 조직에서 중요 한 생리적 역할을 한다(Minuk, 1993: Takano et al., 2014). GABAergic 회로의 변경은 파킨슨병 및 노인성 치매와 같

Received: April 15, 2021 / Revised: June 1, 2021 / Accepted: June 4, 2021

* Professor.

${ }^{\dagger}$ Corresponding author: In-Suk Sim. Department of Clinical Laboratory Science, Kyungdong University, Wonju 26495, Korea.

Tel: +82-33-738-1374, Fax: +82-33-738-1379, e-mail: simis@kduniv.ac.kr

(C) The Korean Society for Biomedical Laboratory Sciences. All rights reserved.

(C) This is an Open Access article distributed under the terms of the Creative Commons Attribution Non-Commercial License (http://creativecommons.org/licenses/by-nc/3.0/) which permits unrestricted non-commercial use, distribution, and reproduction in any medium, provided the original work is properly cited. 
은 신경학적 장애와 관련이 있다(Ting Wong et al., 2003). $\mathrm{GABA}$ 는 신장을 포함한 말초 조직에 존재하며, 만성 신 장질환을 예방하고, 신장절제술에 의해 유발된 산화 스트 레스를 개선하고, 간과 신장기능에 영향을 줄 수 있다 (Sasaki et al., 2006). 다른 연구는 GABA가 유선, 결장 및 간암세포와 같은 다양한 유형의 암세포의 침윤과 전이를 지연시키거나 억제할 수 있다고 제안하였으며, 항염증 및 섬유 아세포 증식을 촉진하여 피부 상처의 치유에 도움 을 준다고 보고되었다(Kleinrok et al., 1998; Minuk, 2000; Opolski et al., 2000; Han et al., 2007).

Erythropoietin (EPO)은 신장에서 생성된 사이토카인으로 골수에서의 적혈구 생성을 조절한다(Salahudeen et al., 2008). 성인에서 $\mathrm{EPO}$ 는 신장 피질의 섬유 모세포에 의해 생성되 며, hypoxia inducible factor (HIF)로 인해 EPO 유전자의 전 사를 조절한다(Haase, 2006; Jelkmann, 2013). EPO 생성은 Janus kinase 신호전달 경로의 활성화 및 protein kinase B 의 인산화 및 apoptosis의 억제를 통해 EPO receptor 복합 체에 결합함으로써 신장 보호 효과를 나타낸다(Buemi et al., 2003; Chatterjee, 2007).

최근에 보고된 문헌에 의하면, $\mathrm{GABA}$ 의 섭취로 인해 돼지의 신장 상피세포주에서 $\mathrm{EPO}$ 와 $\mathrm{EPO}$ receptor의 발현 이 증가된 보고가 있는 바(Lee et al., 2018; Shin et al., 2019), 본 연구에서는 Hep3B cell과 흰쥐에게 $\mathrm{GABA}$ 를 투여 후 저산소 환경에 노출시키고 $\mathrm{EPO}$ 및 그와 관련된 유전자 발현을 분석 및 혈액 내 실제 $\mathrm{EPO}$ 수치를 분석하였다. 저산소 환경에서 $\mathrm{GABA}$ 로 인한 $\mathrm{EPO}$ 생성과정의 기전 변 화를 분석하였으며, in vitro와 in vivo에서의 발현양상의 차 이를 확인하였다.

\section{재료 및 방법}

\section{세포 배양}

본 실험에서 사용한 Human hepatoma cell line, Hep3B cell은 한국세포주은행(Seoul, Korea)에서 분양 받았다. $100 \mathrm{~mm}$ culture dish에서 $10 \%$ fetal bovine serum, $1 \%$ penicillin /streptomycin을 함유한 Dulbecco's Modified Eagle's Medium $(\mathrm{DMEM})$ 을 사용하여 $37^{\circ} \mathrm{C}, 5 \% \mathrm{CO}_{2}$ 조건에서 배양하였다. 96-well plate의 각 well마다 $1 \times 10^{4}$ 개의 세포를 seeding 한 후 24시간 동안 배양시켰다. 그 후 혈청이 포함되지 않은 배지로 교환한 후 대조그룹에는 distilled water, 실 험그룹에는 각각 $1 \mu \mathrm{M}, 10 \mu \mathrm{M}, 50 \mu \mathrm{M}, 100 \mu \mathrm{M}, 250 \mu \mathrm{M}$, $500 \mu \mathrm{M}, 1,000 \mu \mathrm{M}$ 의 $\mathrm{GABA}$ 를 처리하였다. 다시 24시간
Table 1. Composition of experimental diets

\begin{tabular}{lc}
\hline \hline \multicolumn{1}{c}{ Ingredients } & $\%$ \\
\hline Protein & 23.0 \\
Carbohydrate & 49.5 \\
Fiber & 6.0 \\
Fat & 4.5 \\
Others & \\
Calories $(\mathrm{kcal} / \mathrm{g})$ & 17.0 \\
\hline
\end{tabular}

Normal laboratory diet (Purina LabDiet 5001)

*Others: vitamins, minerals, and water

동안 배양시킨 후 배지를 제거하고 $0.5 \mathrm{mg} / \mathrm{mL}$ 의 MTT (3-(4,5-dimethylthiazol-2-yl)-2,5-diphenyltetrazolium bromide)를 $100 \mu \mathrm{L}$ 첨가하여 formazan을 형성한 후 DMSO (Dimethyl sulfoxide) $50 \mu \mathrm{L}$ 를 첨가하여 Versamax microplate reader (Molecular devices, Sunnyvale, CA, USA)를 사용하여 흡광도 $(540 \mathrm{~nm})$ 를 측정하였다. EPO 관련 유전자 발현분석을 위 한 세포배양 조건은 MTT 실험 조건과 동일하게 진행하 였으며, GABA의 첨가수준을 $50 \mu \mathrm{M}, 100 \mu \mathrm{M}, 500 \mu \mathrm{M}$ 수 준으로 조정하였다.

\section{세포 저산소 환경 조성}

저산소증은 다양한 세포의 성장에 영향을 주며 활성산 소종을 생성시켜 apoptosis를 야기한다. 따라서 저산소증 을 유도할 수 있는 $\mathrm{CoCl}_{2}$ 를 이용하여 세포실험을 수행하 였다. $\mathrm{Hep} 3 \mathrm{~B}$ 세포를 계대배양하고 $\mathrm{GABA}$ 를 여러 농도로 5 일간 처리하였으며, 12 시간 후에 $\mathrm{CoCl}_{2}$ 를 $50 \mu \mathrm{M}$ 의 농도 로 첨가하였다. $\mathrm{CoCl}_{2}$ 처리 4 시간 후 세포를 모아 분석에 사용하였다.

\section{실험동물}

실험동물은 5 주령의 수컷 Sprague-dawley rat을 (주)코아 텍(평택, 한국)에서 구입하여 1 주일간 사육장 환경에 적 응시킨 후 그룹당 8 마리씩 무작위로 나누어 사용하였다. $\mathrm{GABA}$ 를 3주간 $1 \mathrm{mg} / 100 \mathrm{~g} \mathrm{BW}, 5 \mathrm{mg} / 100 \mathrm{~g} \mathrm{BW}, 10 \mathrm{mg} /$ $100 \mathrm{~g} \mathrm{BW}$ 의 농도로 경구투여 했으며, 이후 5일 동안에도 $\mathrm{GABA}$ 를 섭취 및 하루 1 시간씩 저산소 환경에 노출시켰 다. 물과 사료는 자유롭게 섭취하도록 하였고 사용한 사 료는 설치류 사료(LabDiet 5001 Rodent Diet, Purina, Table 1) 를 사용하였다. 사육장의 실내온도는 $22 \pm 4^{\circ} \mathrm{C}$, 습도 $60 \pm$ $10 \%$, 조도는 200 300 Lux로 유지하였으며, 12시간 명암주 기가 되도록 조절하였다. 동물실험은 고려대학교 동물윤 
Table 2. Primer sequences

\begin{tabular}{lll}
\hline \hline Gene symbol & \multicolumn{1}{c}{ Sense (5'-3') } & \multicolumn{1}{c}{ Antisense (5'-3') } \\
\hline EPO & TACGTAGCCTCACTTCACTGCTT & GCAGAAAGTAT CG TGTGAG TGT TC \\
EPOR & AGGTGGACGTGTCAGCAGGC & CGTACCTTGTGGCGTATGCAG \\
HIF-1a & CACTGCACAGGCCACATTCAT & AAGCAGGTCATAGGCGGTTTC \\
HIF-2a & GTCACCAGAACTTGTGC & CAAAGATGCTGTT \\
JAK-2 & GGCAGCAGCAGAACCTAC & GTCTAACACCGCCATCCC \\
VEGF & AACGAAAGCGCAAGAAATCC & GCTCACAGTGAACGCTCCAG \\
Actin & CTTTCTACAATGAGCTGCGTG & TCATGAGGTAGTCTGTCAGG \\
\hline
\end{tabular}

EPO, erythropoietin; EPOR, erythropoietin receptor; HIF, hypoxia inducible factor; JAK-2, janus kinase 2; VEGF, Vascular endothelial growth factor

리위원회의 승인(Approval No. KUIACUC-2017-95)을 얻어 수행하였다. 실험이 종료된 후 각 동물의 신장부분을 적 출하여 EPO 및 이와 관련된 유전자 발현분석에 사용하 였다. 혈액은 안락사 후 모든 동물에서 채혈하였으며, 혈 구분석은 EDTA가 첨가된 진공 혈액 튜브에 넣어 분석 시 까지 $4{ }^{\circ} \mathrm{C}$ 에 보관하고, 4 시간 내에 rat 전용 혈구분석장비 를 사용하여 분석하였다. 혈청분석은 항응고제가 없는 진공튜브를 사용하였고, $3,000 \mathrm{rpm}$ 에서 10 분간 원심분리하 여 상층 혈청을 $\mathrm{EPO}$ 분석에 사용하였다.

\section{동물 저산소 환경 조성}

저산소 환경은 외부 공기와 차단된 hypoxia chamber (COY, $\mathrm{O}_{2}$ Control In Vivo Cabinet, USA)를 사용하였다. Hypoxia pump를 이용하여 chamber 내로 산소농도 $9 \%$, 질 소 $92 \%$ 가 되도록 조성하였으며, 하루 30 분 동안 노출시 켰다.

\section{혈청 및 세포 내 EPO 분석}

혈청 및 세포의 EPO 분석은 ELISA kit (Cat\# CSB-07323r, CUSABIO CO., LTD, China)를 사용하였다.

\section{Reverse transcription-polymerase chain reaction}

실험이 종료된 동물의 신장 부위를 적출하였고, 조직 당 동일부분에서 RNeasy min kit (QIAGEN)을 사용하여 매뉴얼에 따라 RNA를 분리하였다. 분리된 RNA는 $1^{\text {st }}$ strand cDNA kit (Roche)를 사용하여 cDNA를 합성하였다. 10X buffer $2.0 \mu \mathrm{L}, 25 \mathrm{mM} \mathrm{MgCl} 4.0 \mu \mathrm{L}$, dNTP $2.0 \mu \mathrm{L}$, oligodT primer $2.0 \mu \mathrm{L}$, RNasin $1.0 \mu \mathrm{L}$, AMV reverse transcriptase $0.8 \mu \mathrm{L}$ 의 mixture에 RNA $500 \mu \mathrm{L}$ 을 첨가하여 sterile water 로 $20.0 \mu \mathrm{L}$ 가 되게 한 후, Thermo cycler (9700, Applied biosystem)에서 $25^{\circ} \mathrm{C}$ 에서 10 분, $42^{\circ} \mathrm{C}$ 에서 60 분, $95^{\circ} \mathrm{C}$ 에서 5 분간 반응시켜 $\mathrm{cDNA}$ 를 합성하였다. 합성된 $\mathrm{cDNA}$ 는 $2 \mathrm{X}$ probe mixture (Roche)를 사용하여 LC480 realtime PCR 장비 (Roche)에서 발현량을 분석하였다. 2X LC480 probe master mix (Roche) $10 \mu \mathrm{L}, 20 \mathrm{pM}$ forward 및 reverse primer $1.0 \mu \mathrm{L}$, $20 \mathrm{pM}$ probe $0.2 \mu \mathrm{L}$ 의 mixture에 cDNA $1.0 \mu \mathrm{L}$ 를 첨가하여 sterile water로 $20 \mu \mathrm{L}$ 가 되게 한 후, $\mathrm{LC} 480$ realtime $\mathrm{PCR}$ 장비(Roche)로 $95^{\circ} \mathrm{C}$ 에서 3 분간 predenaturation, $95^{\circ} \mathrm{C}$ 에서 10 초, $60^{\circ} \mathrm{C}$ 에서 30 초를 40 회 반복하여 발현량을 $2-\Delta \Delta \mathrm{Ct}$ 법 으로 분석하였다. 모든 실험은 2회 반복하였으며, PCR에 사용된 유전자의 이름 및 염기서열은 Table 2 와 같다.

\section{통계처리}

통계분석은 SPSS program (SPSS Inc., Chicago, USA)을 이 용하여 평균과 표준편차 $($ mean $\pm \mathrm{SD})$ 로 제시하였으며, 각 그룹의 유의성 분석은 시험그룹의 측정치에 대해 Student $t$-test 검정을 적용하여 $P<0.05$ 이하의 유의수준에서 유의 성 검정을 실시하였다. 처리구간의 유의성은 Duncan's multiple range-test를 이용하여 $5 \%$ 수준에서 검정하였다.

\section{결과 및 고찰}

\section{세포 독성}

Hep3B cell을 배양시킨 후 $\mathrm{GABA}(1 \mu \mathrm{M}, 10 \mu \mathrm{M}, 50 \mu \mathrm{M}$, $100 \mu \mathrm{M}, 250 \mu \mathrm{M}, 500 \mu \mathrm{M}$ )를 24시간 동안 처리하여 MTT로 Cell viability를 측정한 결과, 대조그룹에 비해 각각 $98.90 \%$, $98.07 \%, 99.67 \%, 103.43 \%, 103.38 \%, 100.24 \%, 102.34 \%$ 로 나 타났으며 GABA가 Hep3B cell에 독성을 나타내지 않는다 는 것을 확인하였다(Fig. 1). 


\section{세포 내 EPO 및 관련 유전자 발현}

$\mathrm{Hep} 3 \mathrm{~B}$ cell을 $\mathrm{CoCl}_{2}$ 에 노출시킨 후 세포 내 $\mathrm{EPO}$ 와 관 련 유전자들의 발현을 분석하였다(Fig. 2). 세포 내 $\mathrm{EPO}$ 의

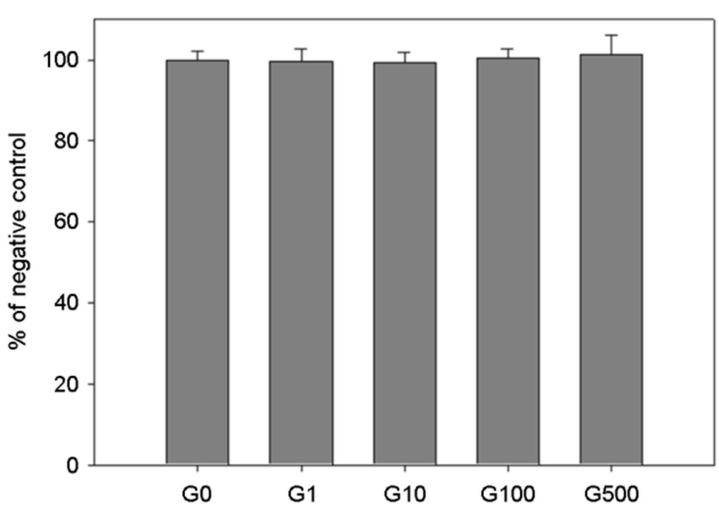

Fig. 1. MTT Assay in co-culture of Hep3B cells after an overnight incubation with $1,10,100$ and $500 \mu \mathrm{g} \mathrm{GABA} / \mathrm{mL}$. The absorbance of the MTT formazan was determined at $570 \mathrm{~nm}$ in an ELISA reader. Cell viability was defined as the ratio (expressed as a percentage) of absorbance of treated cells to untreated cells. Values given represent the mean \pm standard deviations of three independent experiments carried out in triplicates.
발현은 대조그룹에 비해 $\mathrm{G} 0$ 그룹에서 약 8.7배 증가하였 으며, GABA 첨가그룹인 $\mathrm{G} 50, \mathrm{G} 100, \mathrm{G} 200$ 그룹에서는 $\mathrm{G} 0$ 그룹에 비해 각각 $55.7 \pm 3.77 \%, 39.3 \pm 2.80 \%, 37.1 \pm 2.14 \%$ 로 유의하게 증가하였다. $\mathrm{EPO}$ receptor의 발현분석 결과 $\mathrm{NC}$ 그룹에 비해 모든 그룹에서 약 $34.3 \pm 1.1 \%$ 의 수준으로 유 의하게 감소하였다. Janus kinase 2 (JAK2)의 발현분석 결 과에서도 $\mathrm{NC}$ 그룹에 비해 모든 그룹에서 약 $37.2 \pm 7.25 \%$ 수준으로 유의하게 감소하였다. 반면 $\mathrm{VEGF}$ 의 발현분석 결과, $\mathrm{NC}$ 그룹에 비해 $\mathrm{G} 0$ 그룹에서 약 $53.1 \pm 6.54 \%$ 가 증 가하였으며, $\mathrm{G} 50, \mathrm{G} 100, \mathrm{G} 500$ 첨가그룹에서는 $\mathrm{G} 0$ 그룹에 비해 각각 $23.5 \pm 9.58 \%, 28.8 \pm 8.12 \%, 26.8 \pm 5.14 \%$ 증가하 였으나 유의적이지는 않았다. HIF-1의 발현분석 결과 $\mathrm{NC}$ 그룹에 비해 $\mathrm{G} 0$ 그룹에서 $60 \pm 1.88 \%$ 증가하였으며, $\mathrm{G} 500$ 그룹에서 유일하게 $\mathrm{G} 0$ 그룹에 비해 $8.1 \pm 2.94 \%$ 유의하게 감소하였다. HIF-2의 발현분석 결과 HIF-1과 유사한 결과 가 확인되었다. $\mathrm{NC}$ 그룹에 비해 $\mathrm{G} 0$ 그룹에서 $73 \pm 2.32 \%$ 증가하였으나, G500 그룹에서 $\mathrm{G} 0$ 그룹에 비해 유일하게 $26.0 \pm 1.56 \%$ 감소하였다.

$\mathrm{EPO}$ 는 신장과 간에서 생성되며, 저산소 상태로 있으면 $\mathrm{EPO}$ 의 생산이 항진되어 혈장 $\mathrm{EPO}$ 가 증가하며, 이것이
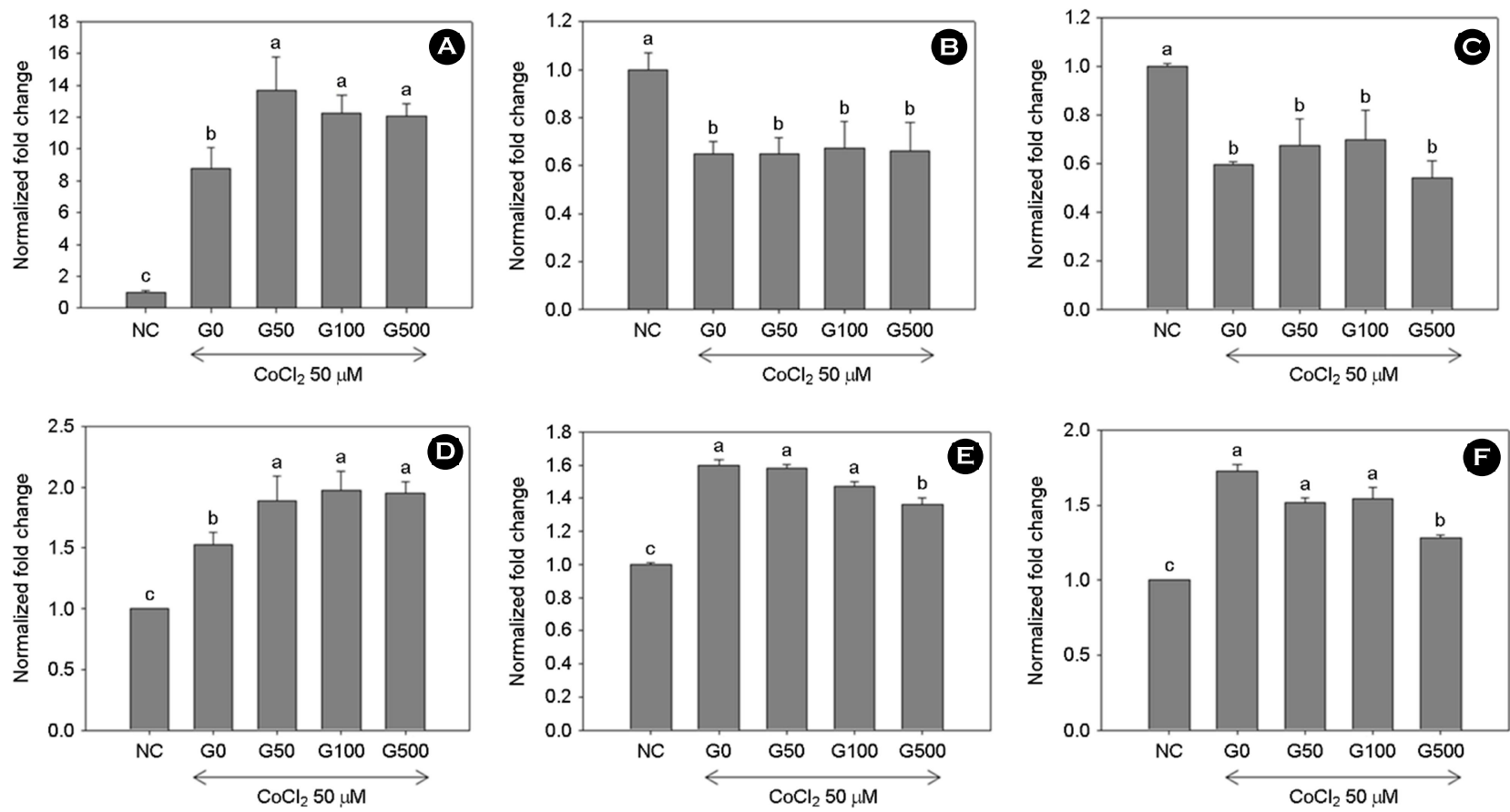

Fig. 2. Effect of different concentrations of GABA on EPO and its related gene expression in Hep3B cell exposed to hypoxia. Gene expression of (A) EPO, (B) EPO receptor, (C) JAK-2, (D) VEGF, (E) HIF-1, (F) HIF-2. Data represent ration in mean \pm SEM of experiment Different letters indicate significant difference of the means $(P<0.05)$. EPO, erythropoietin; JAK-2, janus kinase 2; HIF-1, hypoxia inducible factor 1; HIF-2, hypoxia inducible factor 2; VEGF, vascular endothelial growth factor. 

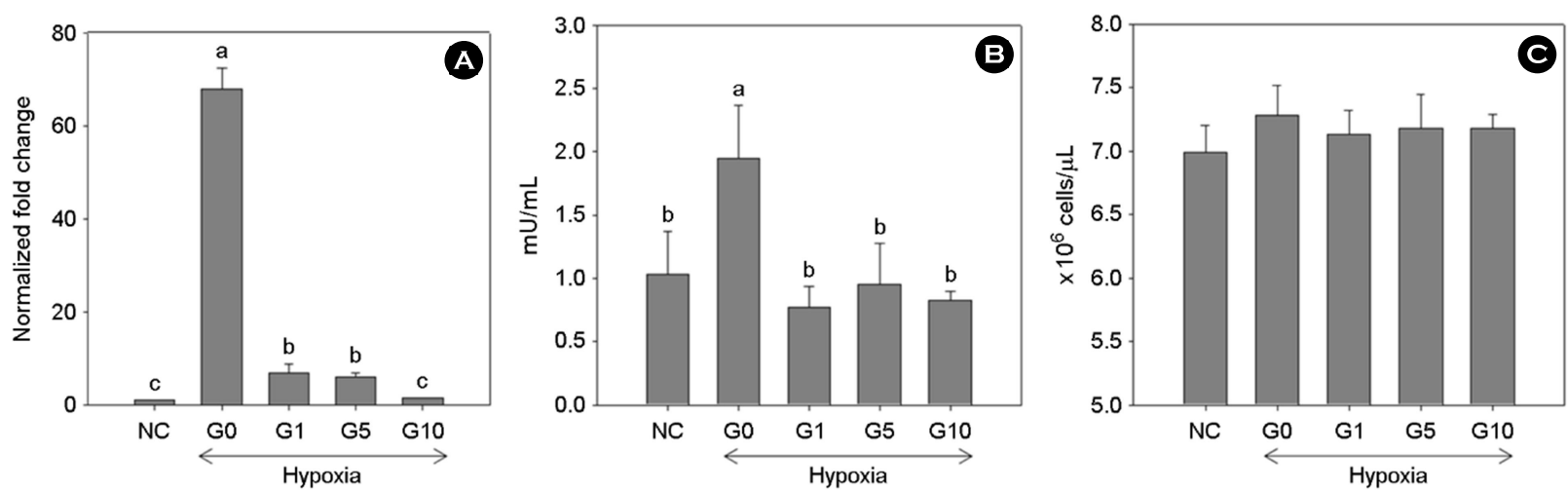

Fig. 3. Effects of different concentrations of GABA on EPO and its related genes in rat kidney exposed to hypoxia. (A) Gene expression of EPO in kidney tissues, (B) EPO value of serum, (C) Red blood cell counts in whole blood. Data represent ration in mean \pm SEM of experiment. Different letters indicate significant difference of the means $(P<0.05)$. EPO, Erythropoietin.

골수의 간세포에 작용하여 적혈구로의 분화를 유도한다 (Silver and Erslev, 1974; Jelkmann, 2007). 본 실험에서도 5일 간 1시간씩 저산소 환경을 조성한 $\mathrm{CoCl}_{2}$ 처리 그룹에서 도 $\mathrm{EPO}$ 의 발현량이 약 8배 이상 증가하였다. $\mathrm{GABA}$ 를 처 리한 그룹에서도 $\mathrm{EPO}$ 의 발현량이 유의하게 증가하였으 며, 세포 내에서 $\mathrm{GABA}$ 가 $\mathrm{EPO}$ 를 증가시킨다는 보고와 일치하였다(Lee et al., 2018). 하지만, EPO receptor 발현량 분석 결과 $\mathrm{GABA}$ 를 처리하지 않은 그룹인 $\mathrm{G} 0$ 그룹에서 는 $\mathrm{NC}$ 에 비해 유의하게 감소하였으며, $\mathrm{GABA}$ 를 처리하 여도 증가하지 않았다. 일반적으로 고산지대와 같이 저산 소 환경에 노출이 되면 $\mathrm{EPO}$ 및 $\mathrm{EPO}$ receptor의 발현이 증 가하여, 빈혈에 상응하는 방어기작을 작동시킨다. 이로 인 해 적혈구와 헤모글로빈의 양을 증가시키고 잠정적으로 산소 운반 능력을 향상시킨다. 본 실험은 고산지대와 같 은 저산소 환경과는 다르게 하루 1 시간씩 5 일간, 매우 간 헐적으로 저산소 환경에 노출시켰기 때문에 $\mathrm{EPO}$ 와 $\mathrm{EPO}$ receptor의 동시적인 발현이 일어나지 않았을 것으로 생각 된다.

$\mathrm{EPO}$ 는 EPO receptor와 결합하여 JAK-STAT (signal transducers and activators of transcription) 신호전달에 의해 조절 된다. Dimer 형태의 receptor에 $\mathrm{EPO}$ 가 결합하면 수용성 단백질인 $\mathrm{JAK}$ 와 결합하여, 신호전달과 전사활성인자인 STAT의 활성이 일어난다(Won et al., 2009). 본 실험에서 도 GABA가 EPO receptor의 발현에 영향을 미치지 않았 기 때문에, JAK2의 발현 역시 차이가 없었던 것으로 확인 되었다. 세포가 저산소 상태에서 생존하고 필요한 산소를 얻기 위해 hypoxia response element는 물론 300 여개의 유 전자에 영향을 미치며, 이 중에서도 혈관생성촉진인자인
$\mathrm{VEGF}$ 와 $\mathrm{EPO}$ 및 혐기성 대사 관련 유전자가 가장 큰 영 향을 받게 된다(Kimáková et al., 2017). 또한, 암세포가 산 소가 부족한 환경에 적응할 수 있도록 하는 HIF-1 단백 질이 발견되면서 이와 관련된 매우 많은 문헌들이 보고되 고 있다(Kaelin and Ratcliffe, 2008; Pugh and Ratcliffe, 2003). 본 실험 결과 $\mathrm{GABA}$ 의 처리가 $\mathrm{EPO}$ 발현 경향과 동일하 게 $\mathrm{VEGF}$ 의 증가에도 영향을 미친 것으로 나타났다. HIF1 과 $\mathrm{HIF}-2$ 의 유전자 발현분석 결과 $\mathrm{CoCl}_{2}$ 를 처리한 그 룹에서 모두 유의한 증가를 나타냈으며, G500 그룹에서 는 오히려 HIF의 증가를 억제하였다. 일반적으로 HIF는 저산소 환경에 의하여 발현되고 VEGF 발현 증가에도 영향을 미치는 것으로 알려져 있으며, 그 외의 hypoxia inducible gene들의 발현에도 중요한 역할을 한다(Kaelin and Ratcliffe, 2008). 하지만, breast cancer MCF-7 세포 내에 $\mathrm{CoCl}_{2}$ 를 투여 후 저산소 환경을 유도하였을 경우 유전자 발현을 분석하였을 경우 $\mathrm{VEGF}$ 는 유의적으로 증가하였으 나, HIF-1은 유의한 차이를 없었다(Qing et al., 2018). 또한, 세포 내에서 GABA가 비정상적인 $\mathrm{HIF}$ 유전자 발현량을 억제시켜, 생물학적 항상성을 유지시키려는 작용이라고 생각된다.

\section{신장 조직 내 $\mathrm{EPO}$ 유전자 발현 및 혈청 내 $\mathrm{EPO}$ 및 $\mathrm{RBC}$ 수치}

실험 종료 후 신장 조직을 적출하여 동일부분을 분석 에 사용하였다. 신장 조직의 $\mathrm{EPO}$ 발현분석 결과 $\mathrm{NC}$ 그 룹에 비해 G0 그룹에서 약 67.8 배가 증가하였다(Fig. 3). 그에 반해 $\mathrm{G} 1, \mathrm{G} 5, \mathrm{G} 10$ 그룹에서는 각각 $89.8 \pm 26.12 \%$, $91.1 \pm 14.88 \%, 97.9 \pm 2.77 \%$ 로 매우 크게 감소하였다. 
동물의 혈액을 채혈하여 혈청 내 EPO 수치를 분석하 였다. $\mathrm{NC}$ 그룹에 비해 $\mathrm{G} 0$ 그룹에서 약 $89.3 \pm 21.53 \%$ 의 수 치로 증가하였다. 하지만 $\mathrm{G} 0$ 그룹에 비해 $\mathrm{G} 1, \mathrm{G} 5, \mathrm{G} 10$ 그 룹에서 각각 $60.5 \pm 22.08 \%, 51.3 \pm 34.74 \%, 57.4 \pm 8.70 \%$ 의 수치로 유의하게 감소하였다. 또한, 전혈을 이용하여 적 혈구 수를 분석하였으나 그룹 간 유의한 차이는 없었다.

빈혈이 아닌 상태에서 혈액의 EPO 농도는 매우 낮지 만, 저산소 스트레스에서는 약 1,000 배가 높아지며, 주로 신장 피질에서 생산된다(Jacobson et al., 1957; Fisher et al., 1996). $\mathrm{EPO}$ 는 혈액의 산소농도에 따른 $\mathrm{HIF}$ 피드백 기작으 로 조절되며, 산소가 있는 환경에서는 분해된다. 본 실험 에서는 흰쥐에게 간헐적으로 저산소 농도에 노출시키고, $\mathrm{GABA}$ 를 투여하여 $\mathrm{EPO}$ 유전자의 발현량을 분석하였다. 저산소 환경에 노출시킨 $\mathrm{G} 0$ 그룹에서는 $\mathrm{NC}$ 에 비해 발 현량이 약 68 배로 증가하였다. 하지만 $\mathrm{GABA}$ 투여그룹인 $\mathrm{G} 1, \mathrm{G} 5, \mathrm{G} 10$ 에서는 세포실험과 달리 오히려 EPO 발현량 을 크게 억제하였다. 또한, 혈청 내 $\mathrm{EPO}$ 수치를 분석한 결과 $\mathrm{NC}$ 그룹에 비해 $\mathrm{G} 0$ 그룹에서 유의하게 증가하였고, $\mathrm{GABA}$ 처리그룹에서 다시 유의하게 감소하였다. 이는 매 우 급격하게 증가한 $\mathrm{EPO}$ 유전자 발현을 억제하여, 장기적 으로 과도한 적혈구 수의 증가를 방지하는 기전의 작동이 라 생각된다. $\mathrm{EPO}$ 는 정상 상태에서는 일정속도로 분비되 어 혈액농도를 유지하는데, 비정상적인 $\mathrm{EPO}$ 의 증가는 이 차적인 적혈구 증가증을 일으킬 수 있으며 의학적으로 그 원인을 제거하는 것이 원칙이다(Lee and Arcasoy, 2015). 흰쥐의 전혈에서 적혈구 수의 변화를 분석하였으나, 유의 한 변화는 확인되지 않았다. 적혈구의 생성단계는 골수 중의 조혈줄기세포(Stem cell)의 분화세포인 burst-forming unit-erythroid (BFU-E)와 colony-forming unit-erythroid (CFU-E) 를 단계를 지나 proerythroblasts, erythroblasts를 거쳐 적혈 구 생성시킨다(Dulmovits et al., 2017). 이 과정에서 EPO가 영향을 미치는 단계는 BFU-E stage에서 적혈구 생성 전단 계인 erythroblast stage까지이며, 이 시간이 약 8 일 정도 소 요된다. 본 실험에서는 5 일간 간헐적으로 저산소 환경에 노출시켰기 때문에 혈청 내 EPO 수치가 높아졌다 하더 라도 적혈구의 수가 반응하기까지는 그 기간이 짧았을 것으로 예상할 수 있다.

본 연구에서는 인간 간세포와 흰쥐에게 $\mathrm{GABA}$ 를 투여 하고 저산소 환경에 노출시킨 후 $\mathrm{EPO}$ 와 그와 관련된 유 전자의 발현 및 혈청 내 $\mathrm{EPO}$ 수치를 분석하였다. 간세포 에 $\mathrm{CoCl}_{2}$ 를 첨가하여 저산소 환경을 조성 및 노출시켰을 때, $\mathrm{EPO}$ 가 유의하게 증가하였으며, $\mathrm{GABA}$ 처리그룹에서는
더욱 증가하였다. 하지만, $\mathrm{EPO}$ receptor와 $\mathrm{EPO}$ 기전 통로 인 JAK-2의 발현은 GABA 첨가에 의한 변화가 없었으며, 저산소의 반응인자인 혈관생성인자 $\mathrm{VEGF}$ 은 $\mathrm{GABA}$ 첨가 에 의해 발현량은 증가하였다. 저산소에 가장 먼저 반응 하는 유전자인 HIF-1과 HIF-2는 저산소에 노출된 모든 그룹에서 증가하였으며, $\mathrm{G} 500$ 그룹에서는 오히려 과발현 된 HIF 유전자 발현을 억제시켰다.

흰쥐에 산소농도를 절반으로 줄인 저산소 환경에 노출 시킨 후 신장 조직을 적출 및 $\mathrm{EPO}$ 유전자 발현을 분석하 였다. G0 그룹에서 약 68 배의 $\mathrm{EPO}$ 발현이 증가하였으나, $\mathrm{GABA}$ 처리그룹에서 오히려 큰 폭으로 억제시켰다. 흰쥐 의 혈청 내 $\mathrm{EPO}$ 수치 분석 결과 동일한 경향으로 확인 되었으나, 적혈구 수 분석에서는 유의한 차이를 보이지 않았다.

흰 쥐를 일반사육 환경에서 $\mathrm{GABA}$ 를 투여하였을 경우, 혈청 내 $\mathrm{EPO}$ 및 그와 관련된 유전자의 발현이 증가하며, 적혈구의 수 까지 유의하게 증가한다는 보고가 있다(Park et al., 2020). 본 연구에서는 흰 쥐를 실제 저산소 환경에 하루 1시간, 5일간 노출을 시켰으며, 매우 크게 EPO 유전 자의 발현이 증가한 것을 확인하였다. 이에, $\mathrm{GABA}$ 를 투 여하였을 경우 오히려 $\mathrm{EPO}$ 유전자 발현을 억제하는 경 향이 나타났으며, 실제 혈청 내 EPO 수치도 경향이 일치 하였다. 본 실험은 $\mathrm{Hep} 3 \mathrm{~B}$ 세포에 $\mathrm{CoCl}_{2}$ 로 유도한 저산 소 환경보다 더 과도한 유도실험이며, 실제 산소농도를 낮춘 in vivo 실험으로써 체내 호르몬 반응이 급격히 일어 날 것으로 예상된다. $\mathrm{GABA}$ 는 최근 연구를 통해 장신경 계(Enteric nervous system)를 비롯한 말초신경 등 신체 전 반에서 신체 항성성 유지에 중요한 역할을 하고 있다는 사실이 규명되고 있으며(Arne and Helle, 2007), 본 연구 결 과에서도 급격한 호르몬 변화에 대응하기 위한 $\mathrm{GABA}$ 의 항상성 기작이 발현한 것으로 판단된다.

본 연구에서 주목할 것은 GABA 첨가에 의해 세포실험 과 동물실험의 $\mathrm{EPO}$ 발현이 반대 경향으로 확인되었으며, 이는 생체의 조직세포를 분리하여 특정 물질 또는 환경 에 어떻게 반응하는가를 살피는 세포실험과는 다르게 인 간과 공통적인 생체학적 반응이 매우 유사한 동물실험이 기 때문이라고 생각된다.

최종적으로 저산소 상태에서 GABA가 erythropoiesis에 미치는 영향을 분석하였으며, 향후 용혈성 빈혈 및 기타 빈혈 모델에서 $\mathrm{GABA}$ 의 $\mathrm{EPO}$ 생산 연구 및 생리기능 평 가가 수반되어야 할 것이다. 


\section{ACKNOWLEDGEMENT}

This work was supported by Basic Science Research Program through the National Research Foundation of Korea (NRF) funded by the Ministry of Science and ICT (No. 2018R1C1B5086313).

\section{CONFLICT OF INTEREST}

The authors have declared no conflict of interest.

\section{REFERENCES}

Arne S, Helle S. GABA: Homeostatic and pharmacological aspects. Progress in Brain Research. 2007. 3: 320-336.

Buemi M, Cavallaro E, Floccari F, et al. The pleiotropic effects of erythropoietin in the central nervous system. Journal of Neuropathology \& Experimental Neurology. 2003. 62: 228236.

Chapman RF, Stray-Gundersen J, Levine BD. Individual variation in response to altitude training. Journal of Applied Physiology. 1998. 85: 1448-1456.

Chatterjee PK. Novel pharmacological approaches to the treatment of renal ischemia-reperfusion injury: a comprehensive review. Naunyn-Schmiedeberg's Archives of Pharmacology. 2007. 376: $1-43$.

Dulmovits BM, Hom J, Narla A, Mohandas N, Blanc L. Characterization, regulation and targeting of erythroid progenitors in normal and disordered human erythropoiesis. Current Opinion in Hematology. 2017. 24: 159.

Fisher JW, Koury S, Ducey T, Mendel S. Erythropoietin production by interstitial cells of hypoxic monkey kidneys. British Journal of Haematology. 1996. 95: 27-32.

Haase VH. Hypoxia-inducible factors in the kidney. American Journal of Physiology-Renal Physiology. 2006. 291: F271F281.

Han D, Kim HY, Lee HJ, Shim I, Hahm DH. Wound healing activity of gamma-aminobutyric Acid (GABA) in rats. Journal of Microbiology and Biotechnology. 2007. 17: 1661-1669.

Jacobson L, Goldwasser E, Fried W, Plzak L. Role of the kidney in erythropoiesis. Nature. 1957. 179: 633-634.

Jelkmann W. Erythropoietin after a century of research: younger than ever. European Journal of Haematology. 2007. 78: 183205.

Jelkmann W. Physiology and pharmacology of erythropoietin. Transfusion Medicine and Hemotherapy. 2013. 40: 302-309.
Kimáková P, Solár P, Solárová Z, Komel R, Debeljak N. Erythropoietin and its angiogenic activity. International Journal of Molecular Sciences. 2017. 18: 1519.

Kleinrok Z, Matuszek M, Jesipowicz J, Matuszek B, Opolski A, Radzikowski C. GABA content and GAD activity in colon tumors taken from patients with colon cancer or from xenografted human colon cancer cells growing as sc tumors in athymic nu/nu mice. Journal of physiology and pharmacology: an Official Journal of the Polish Physiological Society. 1998. 49: 303-310.

Lee G, Arcasoy MO. The clinical and laboratory evaluation of the patient with erythrocytosis. European Journal of Internal Medicine. 2015. 26: 297-302.

Lee YM, Choi JH, Min WK, Han JK, Oh JW. Induction of functional erythropoietin and erythropoietin receptor gene expression by gamma-aminobutyric acid and piperine in kidney epithelial cells. Life Sciences. 2018. 215: 207-215.

Levine B, Stray-Gundersen J. A practical approach to altitude training. International Journal of Sports Medicine. 1992. 13: S209-S212.

Mazzeo RS. Altitude, exercise and immune function. Exerc Immunol Rev. 2005. 11: 16.

Minuk G. GABA and hepatocellular carcinoma. Molecular and Cellular Biochemistry. 2000. 207: 105-108.

Minuk GY. Gamma-aminobutyric acid and the liver. Digestive Diseases. 1993. 11: 45-54.

Opolski A, Mazurkiewicz M, Wietrzyk J, Kleinrok Z, Radzikowski C. The role of GABA-ergic system in human mammary gland pathology and in growth of transplantable murine mammary cancer. Journal of Experimental \& Clinical Cancer Research: CR. 2000. 19: 383-390.

Park K, Han J, Kim S, Lim Y. Gamma aminobutyric acid increases erythropoietin by activation of citrate cycle and stimulation of hypoxia inducible factors expression in rats. Biomolecule. 2020. 12: 10

Pugh CW, Ratcliffe PJ. Regulation of angiogenesis by hypoxia: role of the HIF system. Nature Medicine. 2003. 9: 677-684.

Qing L, Rong M, Mei Z. $\mathrm{CoCl}_{2}$ increases the expression of hypoxic markers HIF-1a, VEFG and CXC4 in breast cancer MCF-7 cells. Oncology Letters. 2018. 15: 1119-1124.

Salahudeen AK, Haider N, Jenkins J, Joshi M, Patel H, et al. Antiapoptotic properties of erythropoiesis-stimulating proteins in models of cisplatin-induced acute kidney injury. American Journal of Physiology-Renal Physiology. 2008. 294: F1354F1365. 
Sasaki S, Yokozawa T, Cho EJ, Oowada S, Kim M. Protective role of $\gamma$-aminobutyric acid against chronic renal failure in rats. Journal of Pharmacy and Pharmacology. 2006. 58: 1515-1525.

Semenza GL. HIF-1 and human disease: one highly involved factor. Genes \& Development. 2000. 14: 1983-1991.

Shin J, Lee YM, Oh J, Jung S, Oh JW. Effects of gammaaminobutyric acid and piperine on gene regulation in pig kidney epithelial cell lines. Asian-Australasian Journal of Animal Sciences. 2019.

Silver RK, Erslev AJ. The action of erythropoietin on erythroid cells in vitro. Scandinavian Journal of Haematology. 1974. 13: 338-351.

Takano K, Yatabe MS, Abe A, Suzuki Y, Sanada H, Watanabe T, et al. Characteristic expressions of GABA receptors and GABA producing/transporting molecules in rat kidney. PloS One.
2014. 9.

Ting Wong CG, Bottiglieri T, Snead III OC. Gaba, $\gamma$-hydroxybutyric acid, and neurological disease. Annals of Neurology: Official Journal of the American Neurological Association and the Child Neurology Society. 2003. 54: S3-S12.

Won HH, Park I, Lee E, Kim JW, Lee D. Comparative analysis of the JAK/STAT signaling through erythropoietin receptor and thrombopoietin receptor using a systems approach. BMC Bioinformatics. 2009. 10: S53.

https://doi.org/10.15616/BSL.2021.27.2.69

Cite this article as: Yoon J, Sim IS. Effects of GABA on Erythropoiesis in the Hep3B Cell and Rat Exposed to Hypoxia. Biomedical Science Letters. 2021. 27: 69-76. 